\title{
Evaluation of Soft Tissue and Labial Plate of Bone Stability of Immediate Implant in Direct with Socket Shield: A Case Report
}

\author{
Amr Hany Abdullah', Hala Kamal Abdel Gaber ${ }^{2}$ and Doaa \\ Adel-Khattab ${ }^{3 *}$ \\ ${ }^{1}$ Master Periodontology, Faculty of Dentistry, Ain Shams University, Egypt \\ ${ }^{2}$ Professor of Oral Medicine, Periodontology and Diagnosis, Faculty of Dentistry, Ain \\ Shams University, Egypt \\ ${ }^{3}$ Lecturer of Oral Medicine, Periodontology and Diagnosis Department, Faculty of \\ Dentistry, Ain Shams University, Egypt \\ *Corresponding Author: Doaa Adel-Khattab, Lecturer of Oral Medicine, \\ Periodontology and Diagnosis Department, Faculty of Dentistry, Ain Shams \\ University, Egypt.
}

Received: December 15, 2021

Published: January 18, 2022

(C) All rights are reserved by Doaa

Adel-Khattab., et al.

\begin{abstract}
Implant placement is very common these days, esthetic requirements and expectations of patients and dental implant specialists are increasing to a level where both demand a restoration that mimics the natural appearance of a natural teeth. Bundle bone loss accelerates dimensional bone changes which make it impossible to achieve natural looking implant restorations. Multiple techniques have been used to decrease or repair the effect of physiologic bone resorption elicited by extracting a tooth. All soft tissue and bone tissue management have been successful to an extent but haven't reached the ultimate goal, on a consistent level. Partial extraction techniques are showing promising results as the concept of retaining a part of a tooth in areas where it is known to have dimensional changes as buccal plate. The Socket shield have revolutionized the immediate implant placement in preserving the bucco-facial and alveolar ridge high. This case report demonstrates implant placement using immediate implant in direct contact with socket shield that maintained both soft and hard tissue with proper pink esthetic score.
\end{abstract}

Keywords: Soft Tissue; Socket Shield; Immediate Implant

\section{Introduction}

Tooth extraction leads to internal socket healing by bone formation and external alveolar ridge width and height bone resorption [1]. In the esthetic zone the need for sufficient bone and soft tissue volume and presence of interproximal papilla are higher. Color, texture, and shape of peri-implant mucosa are of outmost importance to avoid un-esthetic restorations. Other risk factors maybe lip line level or gingival biotype [2]. Techniques such as immediate implant placement and ridge preservation procedures suggested to preserve the ridge dimension of extraction sockets could not completely reserve the coronal part of facial bone walls, which comprised almost entirely of bundle bone [3]. The principle of socket-shield technique (SST) is as follows, preparation of the root indicated for extraction so that the buccal/facial part remains intact and attached to the buccal plate of bone. The buccal retained part is left unharmed and not mobilized to avoid physiologic postextraction bone loss. An immediately placed implant is palatal to the retained part and in contact with it.

\section{Case Description}

A 24-year-old woman reported with the chief complaint of loose post and core in upper right first premolar and wanted to get it 
replaced. Extraction of the root using Socket Shield technique and rehabilitation, by placing implants in the region was planned. No relevant medical history was found (Figure $1 \mathrm{a}$ ). First step was to split the root into buccal and palatal parts using long shanked fissure burs, the split it done so that palatal and apex of the root are extracted leaving only the coronal buccal part of the root. Osteotomy is performed and implant placed with stability of 42 newton/ $\mathrm{cm}$ and implant stability quotient (ISQ) of 65. Implant was nonfunctionally loaded using a custom-made chair side temporary restoration mimicking soft tissue profile of extracted canine showing clinical steps (Figures 1,2).
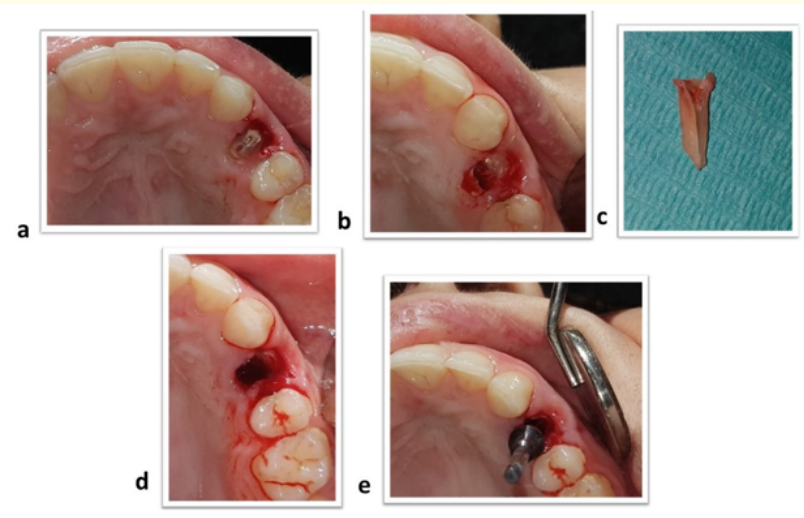

Figure 1: a: Preoperative clinical view, b: Tooth splitting, c: Palatal part extraction, d: Socket shield prepared, e: Osteotomy preparation.
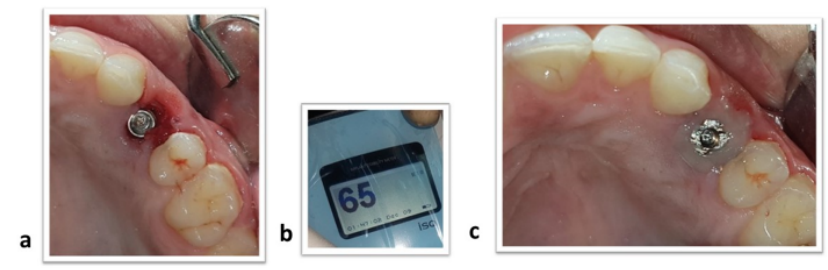

Figure 2: a: Implant placed, b: Implant stability Measurement (ISQ), c: Temporary restoration screwed in.

After 3 months of complete osseointegration, open tray impressions were made, followed by resin trial and metal try in, and the final prosthesis was delivered (Figure 3).

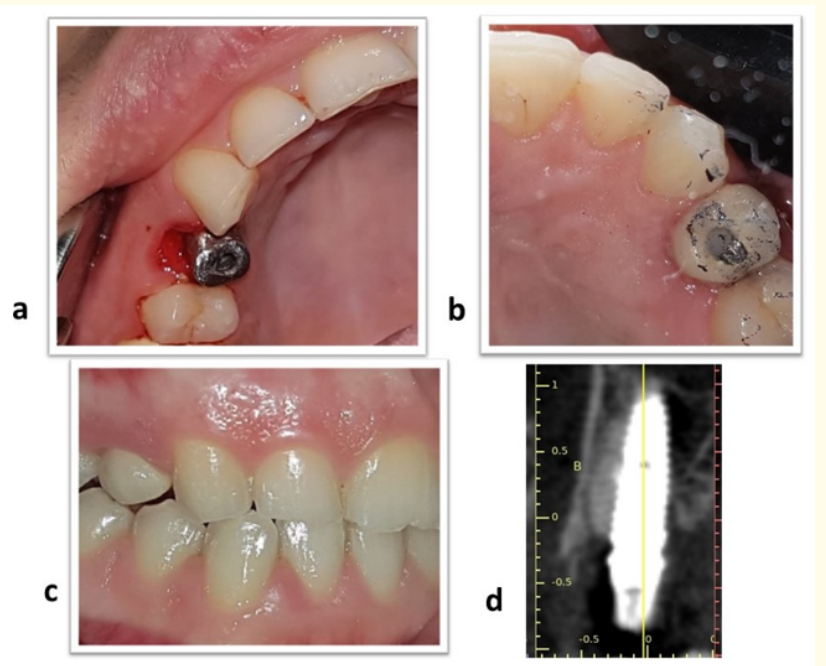

Figure 3: a: Abutment try in, b: Final screw retained porcelain fused to metal crown occlusal adjustment, C: Frontal view, d: Cone beam CT 6 months postoperative.

\section{Results}

The case was properly restored, the width of keratinized gingiva increased from $5.6 \mathrm{~mm}$ preoperatively to 5.7 and $6 \mathrm{~mm} 3$ and 6 months postoperative respectively. the thickness of the gingiva increased from $0.7 \mathrm{~mm}$ preoperatively to $0.8 \mathrm{~mm} 3$ and 6 months postoperative respectively the clinical bone width slightly decreased increased from $7.5 \mathrm{~mm}$ preoperatively to $7.4,7.3 \mathrm{~mm} 3$ and 6 months postoperative respectively. The radiographic crestal bone loss was $0.1 \mathrm{~mm} 6$ months postoperative. The ostell measurement increased from 64 preoperatively to 72 at 6 months postoperatively. Pink esthetic score was maintained 14 at all the intervals (Table 1).

\begin{tabular}{|l|c|c|c|}
\hline & Preoperative & $\begin{array}{c}\text { 3 months } \\
\text { postoperative }\end{array}$ & $\begin{array}{c}\text { 6 months } \\
\text { postoperative }\end{array}$ \\
\hline $\begin{array}{l}\text { Width of } \\
\text { keratinized } \\
\text { gingiva }\end{array}$ & $5.6 \mathrm{~mm}$ & $5.7 \mathrm{~mm}$ & $6 \mathrm{~mm}$ \\
\hline $\begin{array}{l}\text { Thickness of } \\
\text { the } \\
\text { attached } \\
\text { gingiva }\end{array}$ & $0.7 \mathrm{~mm}$ & $0.8 \mathrm{~mm}$ & $0.8 \mathrm{~mm}$ \\
\hline Bone width & $7.5 \mathrm{~mm}$ & $7.4 \mathrm{~mm}$ & $7.3 \mathrm{~mm}$ \\
\hline
\end{tabular}




\begin{tabular}{|l|c|c|c|}
\hline $\begin{array}{l}\text { Radiographic } \\
\text { labial crestal } \\
\text { bone loss }\end{array}$ & & $-0.1 \mathrm{~mm}$ & \\
\hline ostell & $64,65,65$ & & 72 \\
\hline PES & 14 & 14 & 14 \\
\hline
\end{tabular}

Table 1: Clinical and radiographic parameters at socket shield preoperative, 3 and 6 months postoperative.

\section{Discussion}

Physiologic bone resorption is linked to bundle bone following teeth extraction that leads to non-esthetic implant supported restorations, bundle bone resorption is recognized to be more evident in the maxillary anterior buccal alveolus due to the fact that buccal plate in maxillary anterior shows multiple variations most of which the whole buccal plate is composed of merely bundle bone [4].

In the original proof of principle animal study in beagle dogs, Hurzeler., et al. (2010) [5] proved that implant placement using socket shield technique is a viable option and histologically proven that the retained part of the root didn't hinder implant osseo-integration.

Gluckman., et al. (2018) [6] reported in a retrospective evaluation of 128 socket shield cases that the most common complication was the internal exposure of the shield, followed by the external exposure of the shield. This internal exposure prevalence maybe due to the $1 \mathrm{~mm}$ above the crestal bone shield preparation. And reported a $96.1 \%$ survival rate, after 4 years.

In a case-control study in 2014, a medium vertical bone loss of $0.8 \mathrm{~mm}$ was reported in 26 implants on 25 patients after 24 months of follow-up [7]. Since decades, clinicians have been trying to avoid the loss of alveolar volume by leaving root remnants [8]. In an old study on 2000 patients, the authors reported that a $16.2 \%$ of the root remnants resulted in pathological condition signs, especially when exposed to the oral environment. Although numerous papers since the late seventies dealt with the so-called "root submergence technique," this still remains a controversial issue. The uneventful healing of sockets with root fragments has been well documented [9].
A human histologic study has been published recently, showing osseo-integration between an implant surface and a dent in surface of a root fragment from a Socket shield technique, making the technique further promising [10].

\section{Conclusion}

It appears that if the suitable clinical requirements are encountered and the methodical handling of the operator is suitable, the Socket shield technique could minimize the resorption of the buccal tissues after the tooth extraction. In selected cases, the immediate placement of implants with the socket shield technique seems to be a useful tool for the replacement of the teeth lost, especially in the aesthetic area.

\section{Conflicts of Interest}

The authors declare no conflict of interest.

\section{Bibliography}

1. Araújo MG and Lindhe J. "Ridge alterations following tooth extraction with and without flap elevation: an experimental study in the dog". Clinical Oral Implants Research 20.6 (2009): 545-549.

2. De Rouck T., et al. "Immediate single-tooth implants in the anterior maxilla: a 1-year case cohort study on hard and soft tissue response". Journal of Clinical Periodontology 35.7 (2008): 649-657.

3. Mankoo T. "Contemporary implant concepts in aesthetic dentistry--part 3: adjacent immediate implants in the aesthetic zone". Practical Procedures and Aesthetic Dentistry 16.4 (2004): 327-334.

4. Botticelli D., et al. "Hard-tissue alterations following immediate implant placement in extraction sites". Journal of Clinical Periodontology 31.10 (2004): 820-828.

5. Hürzeler MB., et al. "The socket-shield technique: a proofof-principle report". Journal of Clinical Periodontology 37.9 (2010): 855-862.

6. Gluckman H., et al. "A retrospective evaluation of 128 socketshield cases in the esthetic zone and posterior sites: Partial extraction therapy with up to 4 years follow-up". Clinical Implant Dentistry and Related Research 20.2 (2018): 122-129.

7. Abadzhiev M., et al. "Conventional Immediate Implant Placement and Immediate Placement with Socket-Shield Technique - Which is Better". International Journal of Clinical Medicine Research 1.5 (2014): 176-180. 
8. Casey DM and Lauciello FR. "A review of the submerged-root concept". Journal of Prosthetic Dentistry 43.2 (1980): 128-32.

9. Helsham RW. "Some observations of the subject of roots of teeth retained in the jaws as a result of incomplete exodontia". Australian Dental Journal 5 (1960): 70-77.

10. Mitsias ME., et al. "The Root Membrane Technique: Human Histologic Evidence after Five Years of Function". BioMed Research International 2017 (2017): 7269467.

\section{Assets from publication with us}

- Prompt Acknowledgement after receiving the article

- Thorough Double blinded peer review

- Rapid Publication

- Issue of Publication Certificate

- High visibility of your Published work

Website: www.actascientific.com/

Submit Article: www.actascientific.com/submission.php

Email us: editor@actascientific.com

Contact us: +919182824667 